\title{
Orbicular monzodiorites from the NW part of the Plana pluton - preliminary results
}

\section{Орбикулярни монцодиорити от С3 част на Планския плутон - предварителни резултати}

\author{
Stefka Pristavova ${ }^{1}$, Svetlana Encheva ${ }^{2}$, Petar Petrov ${ }^{3}$, Petko Petrov ${ }^{2}$ \\ Стефка Приставова ${ }^{1}$, Светлана Енчева ${ }^{2}$, Петър Петров ${ }^{3}$, Петко Петров $^{2}$ \\ ${ }^{1}$ University of Mining and Geology "St. Ivan Rilski”, 1 Prof. Boyan Kamenov str., Studentski Grad, 1700 Sofia; \\ E-mail: stprist@mgu.bg \\ ${ }^{2}$ Earth and Man National Museum, Sofia; E-mail: sencheva@abv.bg; petkopet@abv.bg \\ ${ }^{3}$ Sofia University "St. Kliment Ohridski”; Department of Organic Chemistry and Pharmacognosy; \\ E-mail: ppetrov@chem.uni-sofia.bg
}

\begin{abstract}
New for Bulgaria, orbicular rocks among monzodiorite from the NW part of the Plana pluton are presented. They comprise a central core of mafic segregation with gabbro composition (mainly of amphibole and plagioclase), surrounded by pyroxene and plagioclase-rich "shells" or rims, with the outer rim in sharp contact with the monzodiorite matrix.
\end{abstract}

Keywords: orbicular rocks, monzodiorite, Plana pluton.

\section{Introduction}

Crystalline igneous rocks with orbicule textures are a relatively rare phenomenon in nature and represent a petrological phenomenon nowadays. From the beginning of the 19 th century until now, numerous articles about such rocks with a diverse composition from all continents of the Earth have been published. Classic examples are the orbicular granites from Finland and the so-called corsites (orbicular diorites more common in the Island of Corsica). They are characterized by their peculiar texture, with orbicules consisting of concentric shells of felsic and mafic minerals dominated by radial and tangential growth of elongate crystals surrounding a core of varying textural and mineralogical characteristics (Leveson, 1966). Most publications concern granitoid orbicular, and those about basic and ultrabasic ones are rare. The most interesting hypotheses about reasons for their formation in recent years could be summarized as follow: a result of supercooled melts during magma rising to the surface (Negrei et al., 1989), and pressure reduc- tion by degassing of volatile components (Zotov, 1989); mixing of mafic and granodiorite magmas with the formation of multiple enclaves of microdiorites transferred upwards into a magma pipe and invasion of overheated felsite magma with supercooling (Sylvester, 2011); formation in small pods of $\mathrm{H}_{2} \mathrm{O}$-rich silicate melt, overheating as a result of the introduction of mafic magma with the destruction of all existing nuclei and a subsequent slowing of crystallization, leading to supercooling (Smillie, Turnbull, 2014).

\section{Geological setting}

The Plana pluton is well-studied Upper Cretaceous intrusive body situated in the western part of the Srednogorie zone. Many scientists published their results related to the mineralogical, geochemical, structural features of the rocks built up the Plana pluton and hosted low- and high-grade metamorphic, sedimentary and volcanic rock (Boyadjiev, 1971; Bidzhova, Nedialkov, 2006; Nedyalkov et al., 
2010; Georgiev et. al., 2014; Dyulgerov, Stefanov, 2016, etc.). Compositionally, the Plana pluton varies between gabbro, gabbrodiorites, quartz diorites, quartz monzodiorites, quartz monzonites, granodiorites and granites, changing gradually respectively from the periphery (basic varieties) to the center of the plutonic body (Bidzhova, Nedialkov, 2006). The structural, textural and compositional heterogeneity of the Plana pluton indicates a long and complex history of magmatism.

\section{Preliminary results and discussion}

The studied orbicular rocks are cropped out in the periphery of the pluton in the thin elongated zone (width up to $3.0 \mathrm{~m}$ ) with $\mathrm{NW}$ direction next to the contact of the monzodiorite and gabbro (from the first impulse of the Plana pluton, according to Boyadzhiev, 1971) in the SE part of the Zheleznitsa village. This zone is intensively enriched of gabbro enclaves (mafic segregation) and xenoliths from the host rocks of the pluton represented by contact metamorphosed rocks from the DPhC frame without of orbicular structure.

The observed orbicular rocks in the frame of the zone show variable sizes from 2 up to $30 \mathrm{~cm}$ and ellipsoidal (Fig. 1A) to rounded shapes. Most of the studied orbicules comprise of central core built up by a mafic segregation with gabbro composition (mainly of amphibole and altered by minerals of epidote group basic plagioclase), surrounded by pyroxene and plagioclase-rich "shells" or rims, with the outer rim in sharp contact with the monzodiorite matrix. The amphibole participates here as a minor component, concentrated in the boundaries between shells, mainly. Obricules without the described core are presented, also.

The shells of the orbicules are composed of plagioclase-clinopyroxene aggregates with a feathery radial structure in all areas, showing growth from the center to the periphery. At the same time, a concentric-zonal texture is observed, alternating from 2 to 8 concentric zones with elongation and enlargement of the aggregates to the matrix. All shells and rims are texturally diverse, typically comprised of varying proportions of radially and/or tangentially arranged pyroxene and plagioclase with a sharp boarder between them enriched of amphibole and magnetite/ilmenite grains (Fig. 1C, D). Microscopically, plagioclase and pyroxene show clear signs of splitting (dendritic crystals), a sign of high crystallization rate and saturated mineral formation
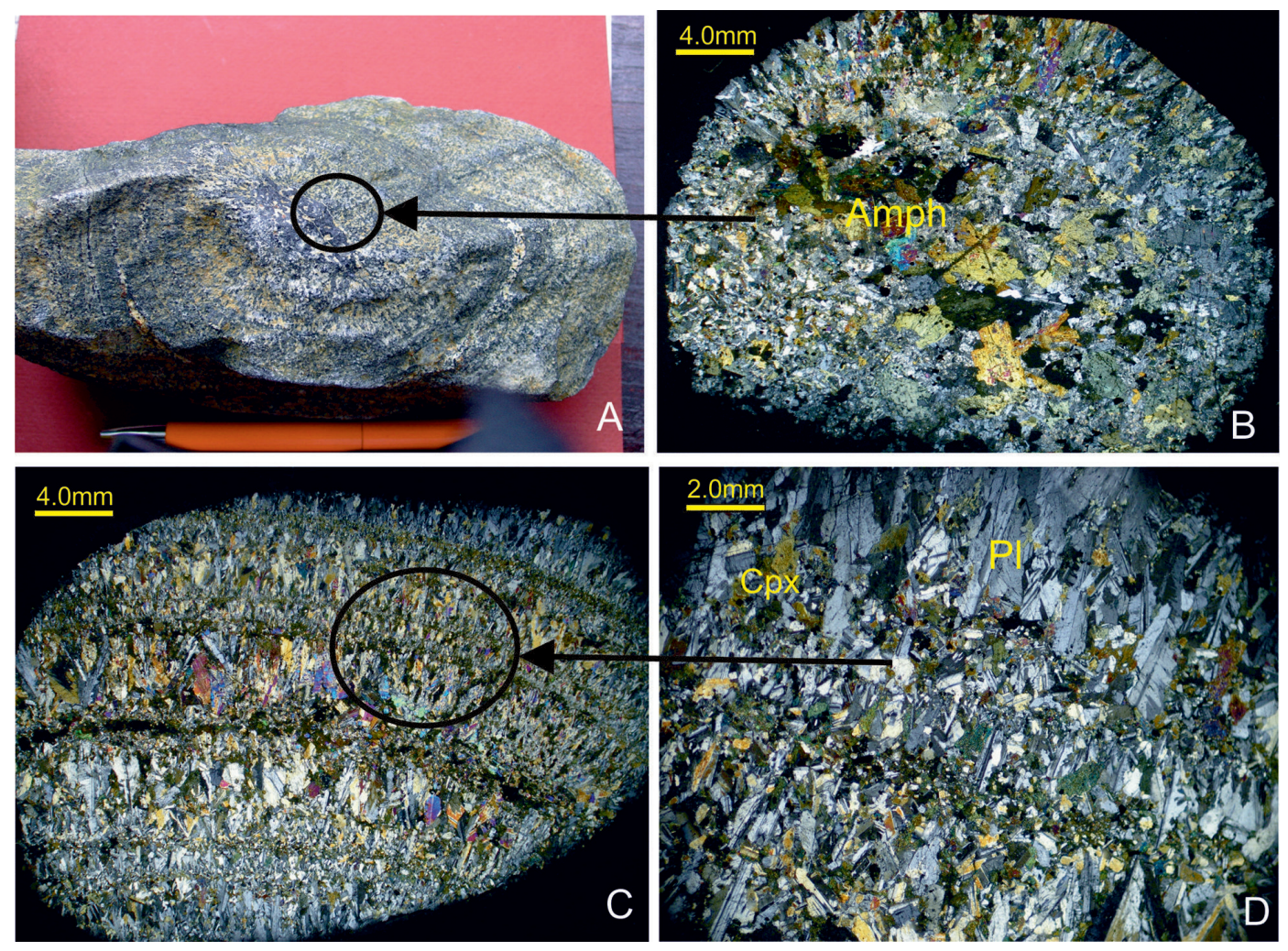

Fig. 1. Photographs of samples from the studied orbiculars: $A$, macrophotograph of the orbicular with ellipsoidal shape and mafic core; $B$, microphotographs of the mafic core; $C, D$, microphotographs of orbicule shells ( $A m p h$, amphibole; $C P x$, clinopyroxene; $\mathrm{Pl}$, plagioclase). Microphotographs were taken by polarized stereomicroscope OLIMPUS, cross-polarized light. 
medium. The contact between orbicule shells and the surrounding monzodiorite host rock is always sharp, suggesting an abrupt change in crystallization conditions.

The preliminary results about mineral composition of the orbicule shells give us information about participation of Mg-rich clinopyroxene, plagioclase with variable composition from $\mathrm{X}_{\mathrm{An}}$ between 24-36 in some grains to $X_{A n} 82-97$ (from core to rim in individual crystals). Mafic core is composed by amphibole represented by magnesio-hornblende and magnesio-ferri hornblende. Similar in composition amphiboles are participate into the shells, also. They show a small higher content of $\mathrm{Ca}$ component and are represented by magnesio-hornblende to pargasite and ferri-chermacite. The amphibole composition is calculated according to Hawthorne et al. (2012).

There are different suggestions of the formation of the Plana pluton: from two different magmatic impulses - the first gabbro and the second intermediate to acid (Boyadjiev, 1971); in situ differentiation in a relatively large magma chamber (Nedyalkov et al., 2010); cumulative origin of gabbro rocks from the peripheral parts of pluton (Bidzhova et al, 2007; Dyulgerov, Stefanov, 2016); vertical uplift of magma with continuous opening with 5 magma pulses and magma mixing processes during the second (Georgiev et al., 2014). In each of these hypotheses could be found some facts supporting one or another aspect concerning the formation of the described orbicular structures but none of them explains the mechanism of their formation.

The rocks with orbicular structures from the NW part of the Plana pluton are new ones for this pluton as well for Bulgaria. It will undoubtedly lead researchers to rethink existing hypotheses about the Plana pluton formation. In order to clarify the orbicule formation the team of this work continues to investigate the mineralogical and geochemical characteristics of these orbicular rocks with possible including experimental modeling of the rock system.

\section{References}

Boyadjiev, S. 1971. Petrology of Plana pluton. - Geochem., Mineral. and Petrogr., 20, 219-242 (in Bulgarian with English abstract).

Bidzhova, L., R. Nedialkov. 2006. Amphiboles from the Plana pluton, Bulgaria. - Proc. Nat. Confer. Bulg. Geol. Soc., Geosciences 2006, 173-176.

Bidzhova, L., R. Nedialkov. 2006. Rock-forming mineral and magmatic enclaves in the Plana pluton, Bulgaria. - Proc. $18^{\text {th }}$ Congress of CBGA. Belgrade, 30-33.

Dyulgerov, M., P. Stefanov. 2016. Cumulative processes in southwestern part of Plana Pluton, Srednogorie zone. Proc. Nat. Confer. Bulg. Geol. Soc., Geosciences 2016, 53-54 (in Bulgarian).

Georgiev, N., B. Henry, N. Jordanova, D. Jordanova, K. Naydenov. 2014. Emplacement and fabric-forming conditions of plutons from structural and magnetic fabric analysis: A case study of the Plana pluton (Central Bulgaria). Tectonophys., 629, 138-154; http://dx.doi.org/10.1016/j. tecto.2014.02.018.

Hawthorne, F. C., R. Oberti, G. Harlow, W. Maresch, R. Martin, J. Schumacher, D. Welch, 2012. Nomenclature of the amphibole supergroup. - Am. Mineral., 97, 2031-2048.

Nedyalkov, R., L. Bidzhova, A. Filipov. 2010. Information about the behavior of $\mathrm{S}$ and $\mathrm{Cl}$ during the formation of the Plana pluton. - Proc. Nat. Confer. Bulg. Geol. Soc., Geosciences 2010, 50-51.

Negrei, E. V., F. T. Suan, E. N. Gramenitsky, F. G. Rafe. 1989. Orbicular granites of the Kent massif (Central Kazakhstan) and the question of their genesis. - Izvestia Akad. Nauk SSSR, Ser. Geol., 3, 17-30 (in Russian).

Smillie, R. W, R. E Turnbull. 2014. Field and petrographical insight into the formation of orbicular granitoids from the Bonney Pluton, southern Victoria Land, Antarctica. - Geol. Mag., 151, 3, 534-549; https://doi.org/10.1017/ S0016756813000484.

Sylvester, A. G. 2011. The nature and polygenetic origin of orbicular granodiorite in the Lower Castle Creek pluton, northern Sierra Nevada batholith, California. - Geosphere, 7, 1-9; https://doi.org/10.1130/GES00664.1.

Levenson, D. J., 1966, Orbicular rocks: A review. - Geol. Soc. Am. Bull., 77, 409-426; https://doi.org/10.1130/00167606(1966)77[409:ORAR]2.0.CO;2.

Zotov, I. A. 1989. Transmagmaticheskie flyuidy v magmatizme i rudoobrazovanii (Transmagmatic Fluids in Magmatism and Ore Formation), Moscow, Nauka, 214 p. 